\title{
Characterization of Source Rocks from Off-shore Niger Delta Basin, Nigeria
}

\author{
OGBESEJANA, AB; BELLO, OM; UDUMA, AU
}

\author{
Department of Applied Chemistry, Federal University Dutsin-Ma, P.M.B. 5001, Dutsin-Ma, Katsina State, Nigeria
}

\begin{abstract}
Rock samples from the offshore Niger Delta basin, Nigeria were characterized by the predominance of $\mathrm{C}_{26} 20 \mathrm{R}+\mathrm{C}_{27} 20 \mathrm{~S}$ TAS peak using GC-MS. Among the compounds identified in $\mathrm{m} / \mathrm{z} 245$ mass chromatograms, $\mathrm{C}_{21}$ methyltriaromatic steroids, $\mathrm{C}_{22}$ methyltriaromatic steroids and $\mathrm{C}_{27}$, 4-methyltriaromatic steroid + $\mathrm{C}_{29}$, 4-methyl-, 24-ethyltriaromatic steroid were the dominant compounds in the rock samples from MJI oilfield while the rock samples from MJO oilfield were characterized by higher abundance of aromatic dinosteroids. All the compounds identified in the $\mathrm{m} / \mathrm{z} 245$ mass chromatograms of rock extracts from OKN were relatively low compared to the rock samples from MJI and MJO oilfields. The source rocks were found to be formed from mixed origin (terrestrial and marine) but with significant contribution of dinoflagellates to the organic matter and deposited in freshwater-brackish/saline lacustrine environment. The source rocks were found to have immature to early oil window maturity status based on the distributions and abundance of triaromatic steroids in the source rocks and this was further supported by well-established maturity parameters based on the saturate and aromatic biomarkers. This study showed that the abundance and distribution of triaromatic steroids and triaromatic dinosteroids can be used to assess the origin, depositional environments and thermal maturity of source rocks in the Niger Delta Basin.
\end{abstract}

DOI: https://dx.doi.org/10.4314/jasem.v22i3.11

Copyright: Copyright (C) 2018 Ogbesejana et al. This is an open access article distributed under the Creative Commons Attribution License (CCL), which permits unrestricted use, distribution, and reproduction in any medium, provided the original work is properly cited.

Dates: Received: 11 February 2018; Revised: 16 March: 2018; Accepted: 30 March 2018

Keywords: Triaromatic steroids, Aromatic dinosteroids, Source rocks, Niger Delta.

Biological markers, or "molecular fossils", which can be identified in extracts of ancient sediments and in crude oils, are routinely used to infer organic facies, depositional environment and thermal history of the host rock or, in the case of petroleum, the source rock(s). Particular classes of molecular fossils in petroleum have found increasing application as age diagnostic markers (Peters et al., 2005). Steranes with 27, 28 and 29 carbons and conventional side chains are important biomarkers for eukaryotic life. Furthermore, those with unconventional side chains offer opportunities for making more specific genetic links between families of organisms and mature sediments and oils (Moldowan et al., 1991).

Triaromatic steroids (TAS) may originate by aromatization and loss of a methyl group $\left(-\mathrm{CH}_{3}\right)$ from monoaromatic steroids (Peters et al., 2005). The $\mathrm{C}_{26}, \mathrm{C}_{27}, \mathrm{C}_{28}$ triaromatic steroids potentially retain genetic information about petroleum and source rocks similar to $\mathrm{C}_{27}, \mathrm{C}_{28}$ and $\mathrm{C}_{29}$ regular steranes. 2005). The cross plot of $C_{26} / C_{28} 20 S$ versus $C_{27} / C_{28}$ $20 \mathrm{R}$ triaromatic steroid ratios have been used to distinguish petroleum systems (Peters et al., 2005). Zhang et al., (2002) and Mi et al., (2007) reported relatively higher abundances of $\mathrm{C}_{26} 20 \mathrm{~S}, \mathrm{C}_{26} 20 \mathrm{R}+$ $\mathrm{C}_{27} 20 \mathrm{~S}$ and $\mathrm{C}_{27}$ 20R TAS in oils derived from Cambrian source rocks, whereas $\mathrm{C}_{28} 20 \mathrm{~S}$ and $\mathrm{C}_{28} 20 \mathrm{R}$
TAS are relatively abundant in oils which originated from Middle-Upper Ordovician carbonate source rocks in the Lunnan oil field, Tarim Basin. Also, triaromatic steroids have been successfully applied to thermal maturity assessment of crude oils and source rocks (Xiangchun et al., 2011; Asif and Fazeelat, 2012).

Triaromatic dinosteroids are important molecular fossil groups derived from dinosterols, compounds known to be the almost exclusive, widely occurring natural products of dinoflagellates (Moldowan and Talyzina, 1998; Wang et al., 2008). The highest concentrations of these compounds are typically found in strata deposited since the beginning of the Mesozoic. However, Moldowan and Talyzina (1998) concluded that dinoflagellate ancestors may date back to the Early Cambrian on the basis of biomarker evidence. Zhang et al. (2002) reported the wide occurrence of 24-norcholestane, dinosteranes and triaromatic dinosteroids with relatively high abundance in extracts from organic rich sediments in Cambrian and Precambrian (Sinian) rocks of the Tarim Basin. Biogeochemical evidence for dinoflagellate ancestors were reported in the Early Cambrian (Withers, 1987) and molecular evidence has provided a link of cyst-forming dinoflagellates with pre-Triassic ancestors (Moldowan and Talyzina, 
1998). These studies suggest that planktonic algae such as dinoflagellates and diatoms may have originated earlier than the Mesozoic.

However, triaromatic steroids and aromatic dinosteroids have not reported or studied in Niger Delta source rocks. This study is conducted to investigate the distributions and geochemical significance of aromatic steroids and aromatic dinosteroids in Niger Delta source rocks.

\section{MATERIALS AND METHODS}

Geological and Stratigraphic Setting: Niger delta is a sedimentary basin situated in the re-entrant of the Gulf of Guinea, West Africa. The sub-aerial portion of the Niger Delta covers approximately 75,000 $\mathrm{km}^{2}$ and stretches about $200 \mathrm{~km}$ from apex to mouth. The total sedimentary prism encompasses $140000 \mathrm{~km}^{2}$, with a maximum stratigraphic thickness of about 12 $\mathrm{km}$ (Whiteman, 1982). The stratigraphy of the thick sedimentary sequence is divided into three lithostratigraphic units, namely the Akata, Agbada and Benin Formations (Short and Stauble, 1967). The uppermost unit, the Benin Formation which ranges from Oligocene to recent in age, comprises continental/fluviatile sands, gravels, and backswamp deposits up to $2500 \mathrm{~m}$ thick. These are underlain by the Agbada Formation of paralic, brackish to marine, coastal and fluvio-marine deposits. These are mainly interbedded sandstones and shale with minor lignite organized into coarsening upward 'offlap' cycles. Underlying this unit is the Akata Formation, ranging in age from Paleocene to Miocene consists of mainly of overpressure shales deposited under fully marine conditions. The depobelts are partitioned into 67east-west bound blocks corresponding to discrete periods of the deltas evolutionary history starting from the oldest in the north, northern delta to the youngest, offshore in the south (Doust and Omatsola, 1990). It is believed that each depobelt constitutes a more or less autonomous unit with respect to sedimentation, structural deformation and hydrocarbon generation and accumulation (Evamy et al., 1978). Available source rocks in the basin exist mainly in the lower parts of the paralic sequence (Agbada Formation) and uppermost strata of the continuous marine shale (Akata Formation; Evamy et al., 1978; Ekweozor and Daukoru, 1994). The hydrocarbon habitat of the Niger Delta is mostly the sandstone reservoir of the Agbada Formation where oil and gas are usually trapped in rollover anticlines associated with growth faults.

Sampling: Twenty one rock samples from the three wells in three fields in offshore Niger Delta were collected and analyzed.
Extraction and analysis: Rock samples were crushed into powder $<100$ mesh and then extracted in batches in a Soxhlet apparatus with $400 \mathrm{ml}$ dichloromethane and methanol (93:7, v:v) for $72 \mathrm{~h}$. The rock extracts were separated into saturated and aromatic hydrocarbon fractions using silica gel/alumina chromatography columns eluted with n-hexane and dichloromethane:n-hexane (2:1, v:v), respectively. The GC-MS analyses of the saturate and aromatic fractions were performed on an agilent 5975i gas chromatography (GC) equipped with an HP-5MS (5\% phenylmethylpolysiloxane) fused silica capillary column (60m x $0.25 \mathrm{~mm}$ i.d., x $0.25 \mu \mathrm{m}$ film thickness) coupled to an agilent $5975 \mathrm{i}$ mass spectrometry (MS). The GC operating conditions are as follows: the oven temperature was held isothermally at $80^{\circ} \mathrm{C}$ for $1 \mathrm{~min}$, ramped to $310^{\circ} \mathrm{C}$ at $3^{\circ} \mathrm{C} / \mathrm{min}$ and held isothermal for $16 \mathrm{~min}$ (Li et al., 2012b). Helium was used as the carrier gas with constant flow rate of $1.2 \mathrm{~mL} / \mathrm{min}$. The MS was operated in the electron impact (EI) mode at $70 \mathrm{eV}$, an ion source temperature of $250{ }^{\circ} \mathrm{C}$ and injector temperature of $285^{\circ} \mathrm{C}$. The identification and elution order of fluorene and its derivatives were determined by comparison of their mass spectra and relative retention times in the corresponding mass chromatograms with those reported in literature (Wang et al., 2008a; Li et al., 2012b).

\section{RESULTS AND DISCUSSION}

Distribution characteristics of triaromatic steroids and aromatic dinosteroids in source rock extracts from Niger Delta Basin: The m/z 231 and 245 mass chromatograms showing the distributions of triaromatic steroids (TAS) and aromatic dinosteroids in the rock samples are shown in Figure 1 and 2, respectively. The peak identities (m/z 245 mass chromatograms) are shown in Table 1. The source rock extracts from MJI oilfield are characterized by higher abundance of $\mathrm{C}_{28} 20 \mathrm{~S}$ and $\mathrm{C}_{28}$ 20R triaromatic steroids while $\mathrm{C}_{26} 20 \mathrm{~S}$ occur as least (Fig. 1). The higher abundance of $\mathrm{C}_{28}$ TAS has been reported in a freshwater lacustrine crude oils from Linnan Subsag, Shandong Province, China (Xiangchun et al., 2011) and crude oils from Ordovician reservoirs from the Tahe oil field, Tarim basin, China (Li et al., 2012b). $\mathrm{OKN}$ and MJO rock samples are characterized by the predominance of $\mathrm{C}_{26} 20 \mathrm{R}+\mathrm{C}_{27} 20 \mathrm{~S}$ TAS peaks while $\mathrm{C}_{28} 20 \mathrm{~S}$ and $\mathrm{C}_{28}$ 20R TAS and $\mathrm{C}_{26}$ 20S occurred relatively low (Fig. 1). Crude oils and source rocks from saline and brackish lacustrine environments have been reported to contain low abundance of $\mathrm{C}_{26}$ TAS (Xiangchun et al., 2011). Also, Cambrian and Lower Ordovician source rocks have been shown to be characterized by lower $\mathrm{C}_{28} 20 \mathrm{~S}$ and $\mathrm{C}_{28}$ 20R TAS and higher $\mathrm{C}_{26} 20 \mathrm{~S}, \mathrm{C}_{27} 20 \mathrm{R}$ and $\mathrm{C}_{26} 20 \mathrm{R}+\mathrm{C}_{27} 20 \mathrm{~S}$ TAS peaks, which is similar to those reported in the 
literature (Zhang et al., 2002; Mi et al., 2007; Li et al., 2012b). There are appreciable quantities of $\mathrm{C}_{20}$ and $\mathrm{C}_{21}$ triaromatic steroids in all the rock samples studied in this work (Fig. 1). Among the methyltriaromatic steroids, dimethyltriaromatic steroids, aromatic dinosteroids and $\mathrm{C}_{29}$, 3-Methyl-, 24-ethyltriaromatic steroids identified in $\mathrm{m} / \mathrm{z} 245$ mass chromatograms, $\mathrm{C}_{21}$ methyltriaromatic steroids, $\mathrm{C}_{22}$ methyltriaromatic steroids and $\mathrm{C}_{27}$, 4methyltriaromatic steroid $+\mathrm{C}_{29}$, 4-methyl-, 24ethyltriaromatic steroid are the dominant compounds in the rock samples from MJI oilfield while one of the peaks of aromatic dinosteroids occurs as the least (Fig. 2). Rock samples from MJO oilfield are characterized higher abundance of aromatic dinosteroids while $\mathrm{C}_{21}$ and $\mathrm{C}_{22}$ methyltriaromatic steroids occur very low (Fig. 2). All the compounds identified in the $\mathrm{m} / \mathrm{z} 245$ mass chromatograms of rock extracts from OKN are relatively low compared to the rock samples from MJI and MJO oilfields. The low abundance of these compounds in OKN rock samples may be linked to their immaturity status. The significant amounts of aromatic dinosteroids observed in the rock samples indicates significant contributions of dinofilagellates into the organic matter that formed the source rocks (Li et al., 2012b; Zhang et al., 2002; Wang et al., 2008a).

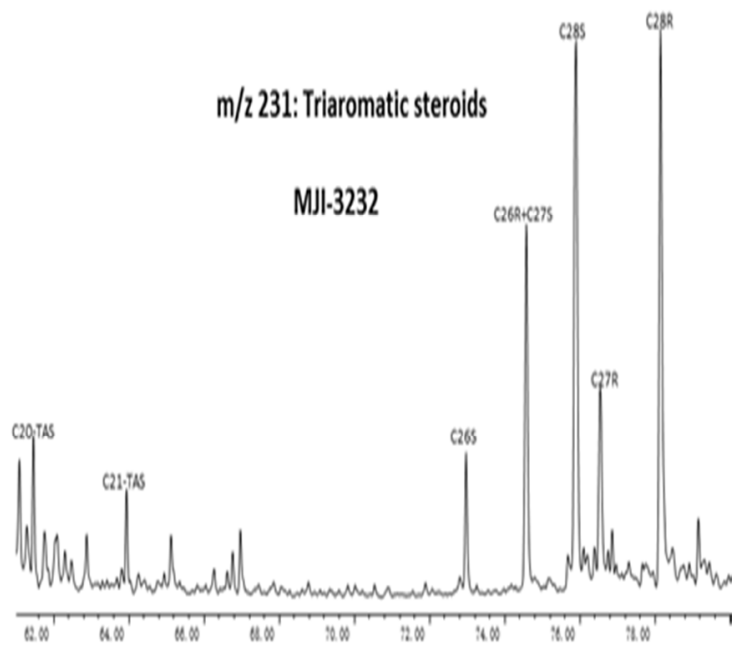

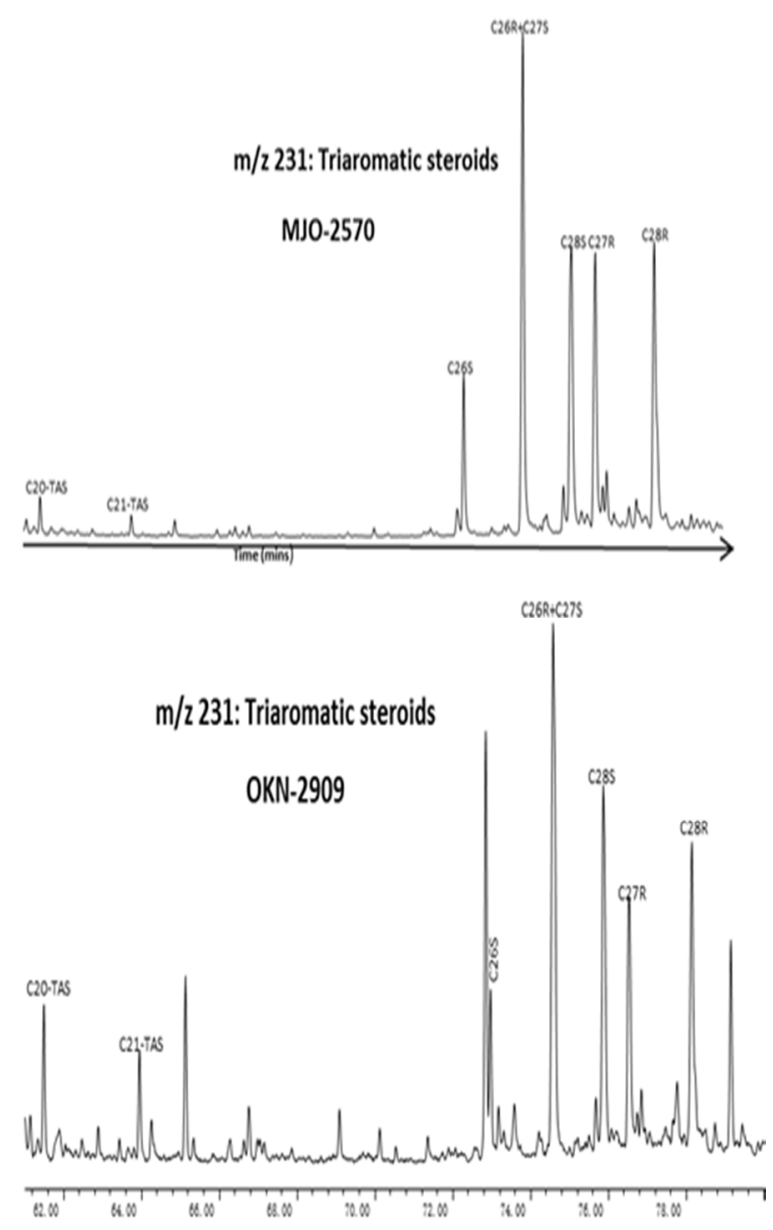

Fig. 1: m/z 231 Mass chromatograms showing the distributions of triaromatic steroids in the source rocks from the Niger Delta

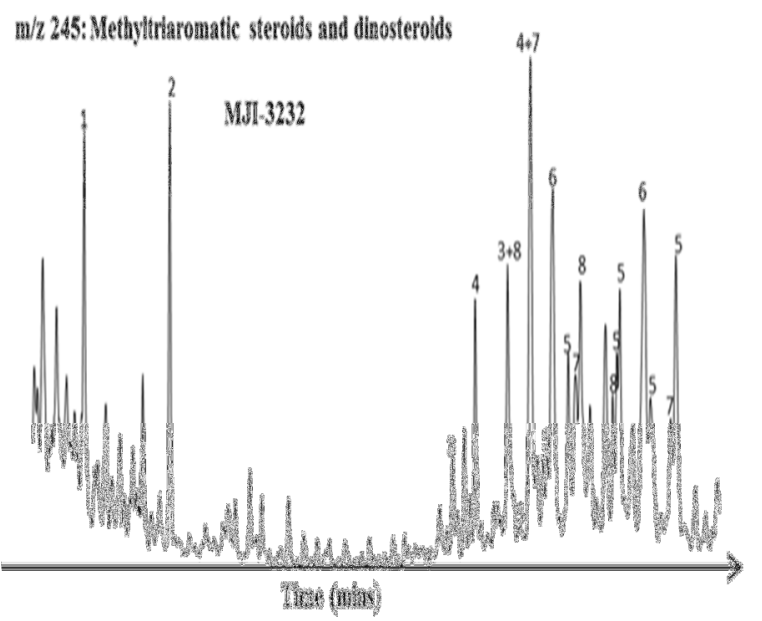



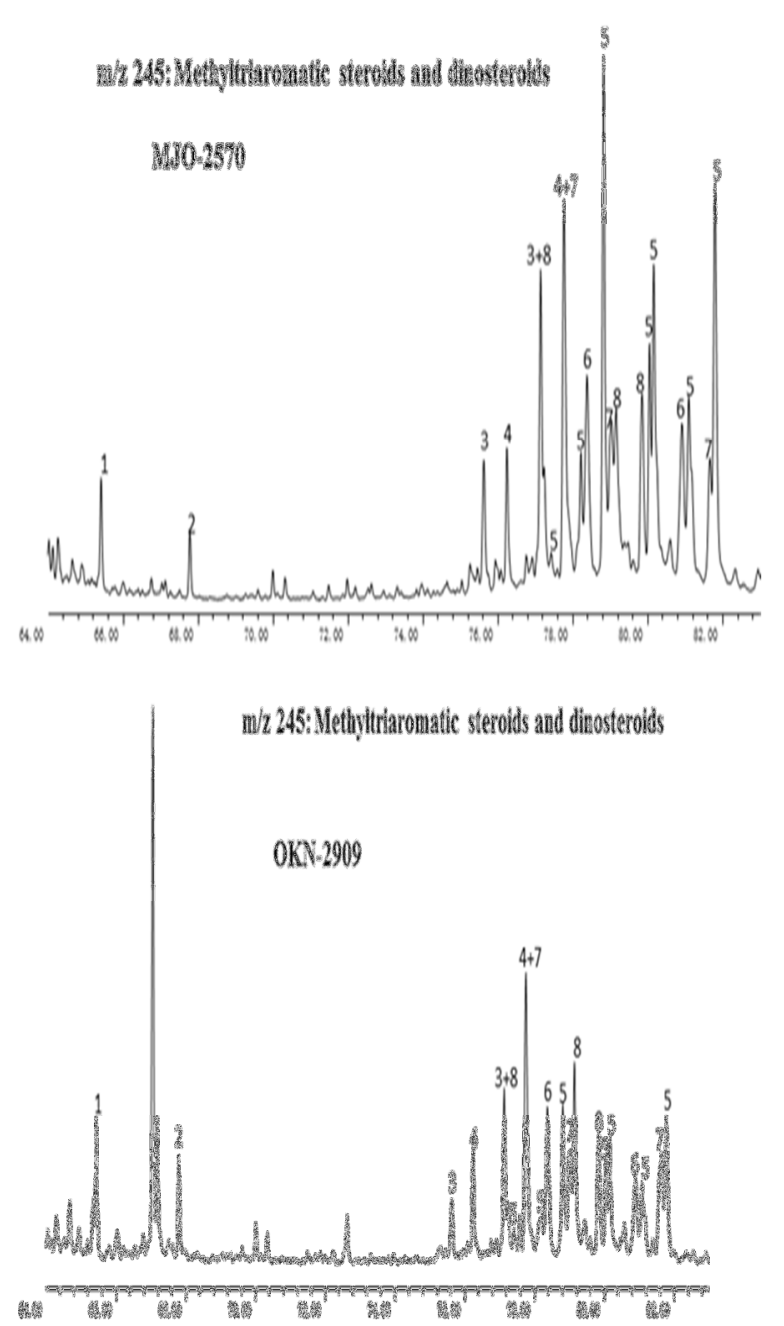

Fig. 2: $\mathrm{m} / \mathrm{z} 245$ Mass chromatograms showing the distributions of methyltriaromatic steroids and aromatic dinosteroids in the source rocks from the Niger Delta

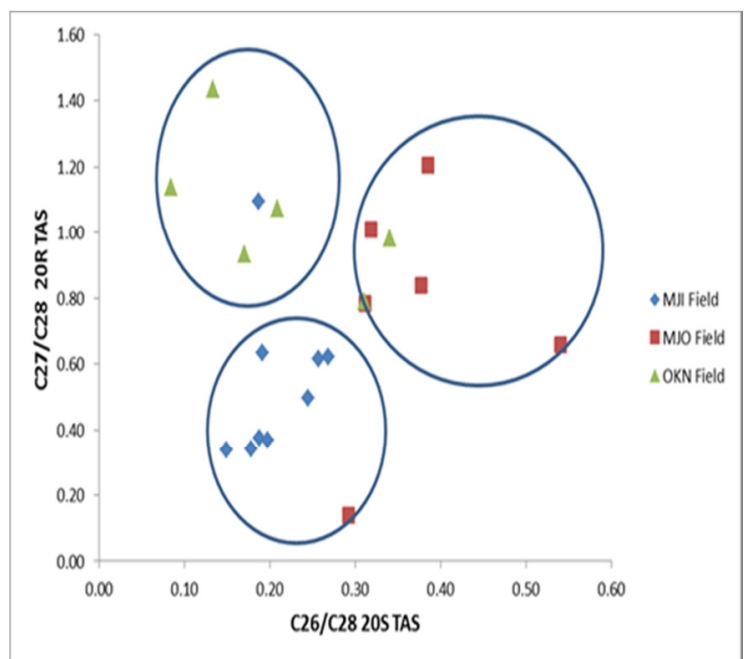

Fig. 3: Cross plots of $\mathrm{C}_{27} / \mathrm{C}_{28}$ 20R TAS versus $\mathrm{C}_{26} / \mathrm{C}_{28} 20 \mathrm{~S}$ TAS for Niger Delta rock samples.
Geochemical significance of triaromatic steroids and aromatic dinosteroids in source rock extracts from Niger Delta Basin: The geochemical parameters computed from triaromatic steroids, aromatic dinosteroids and other geochemical parameters are shown in Table 2. The geochemical parameters are used to determine the origin and maturity status of the Niger Delta source rocks. The distributions of aromatic steroids are influenced by multiple factors and thus can be used as indicator of different source inputs and depositional environments. For example, organic matter formed in fresh water environment is abundant with $\mathrm{C}_{28}$-TAS while in saline and brackish water environments it is abundant with $\mathrm{C}_{26}$-TAS (Xiangchun et al., 2011). The $\mathrm{C}_{26} / \mathrm{C}_{28}-20 \mathrm{~S}$ TAS and $\mathrm{C}_{27} / \mathrm{C}_{28^{-}}$20R TAS ratios for the rock samples range from 0.08 to 0.54 and 0.14 to 1.43 , respectively (Table 2). The low values of $\mathrm{C}_{26} / \mathrm{C}_{28}-20 \mathrm{~S}$ TAS recorded in some rock samples indicate source rock formed a freshwater environment while higher values recorded in some samples indicate a lake environment of brackish-saline water (Xiangchun et al., 2011; Li et al., 2012b). These results show that the source rocks studied are formed from the mixed origin (terrestrial and marine) deposited freshwaterbrackish/saline lacustrine environments. The cross plots of $\mathrm{C}_{26} / \mathrm{C}_{28}-20 \mathrm{~S}$ TAS versus $\mathrm{C}_{27} / \mathrm{C}_{28}-20 \mathrm{R}$ TAS showed that the rock samples from the same field received similar organic material (Fig. 3). The triaromatic dinosteroids are assumed to originate from dinosterol and related sterols, which characterize modern marine dinoflagellates (Moldowan and Talyzina, 1998; Peters et al., 2005). This association suggests that triaromatic dinosteroids are useful biomarkers for improving the recognition of ancient dinoflagellates. The triaromatic dinosteroid hydrocarbon index (TDSI) could be used to reflect the contribution of organic matter from dinoflagellates in the source rocks and crude oils. This parameter has been used to indicate the contribution of dinoflagellates to the oils and source rocks of the Tarim Basin, NW China (Li et al. 2012b) and Paleogene lacustrine sediments from Bohai Bay Basin, China (Wang et al., 2008a). The TDSI values for the rock samples range from 0.53 to 0.79 (Table 2). These values indicate significant contributions of dinoflagellates to the organic matter that formed the source rocks. Progressively more evidence has suggested that dinoflagellates or their ancestors appeared during the Early Cambrian (about $520 \mathrm{Ma}$, Moldowan and Talyzina, 1998) or even Precambrian (Zhang et al., 2002). In this study, the presence of aromatized dinosteroids with extremely high relative concentrations indicates that dinoflagellates or their ancestors lived during the 
Cambrian and Early Ordovician in the seas of Niger Delta.

Ratios of $\mathrm{C}_{26}$-TAS 20S/(20S+20R) and $\mathrm{C}_{28}$-TAS $20 \mathrm{~S} /(20 \mathrm{~S}+20 \mathrm{R})$ are mostly used to evaluate thermal maturity (Xiangchun et al., 2011; Asif and Fazeelat, 2012). In the source rocks studied, the ratios are within the range of 0.10 to 0.40 and 0.11 to 0.63 respectively (Table 2), suggesting immature to early mature characteristics. The Methylphenanthrene index (MPI-1) and 20S/(20S+20R) $\mathrm{C}_{29}$ steranes for the rock samples range from 0.12 to 0.62 and 0.14 to 0.52 respectively (Table 2 ), supporting immature to early oil window maturity status ( Seifert and Moldowan, 1981; Radke, 1988) already inferred from the from the triaromatic steroids based maturity parameters.

Table 1: The peak identities of the compounds identified in $\mathrm{m} / \mathrm{z} 245$ mass chromatograms of aromatic fractions of Niger Delta rock samples.

\begin{tabular}{ll}
\hline Peak Number & Compound \\
\hline 1 & $\mathrm{C}_{21}$ Methyltriaromatic steroid \\
2 & $\mathrm{C}_{22}$ Methyltriaromatic steroid \\
3 & $\mathrm{C}_{27}, 3$-Methyltriaromatic steroid \\
4 & $\mathrm{C}_{27}, 4$-Methyltriaromatic steroid \\
$3+8$ & $\mathrm{C}_{27}, 3$-Methyltriaromatic steroid $+\mathrm{C}_{28}, 3,24$-Dimethyltriaromatic steroid \\
5 & $\mathrm{C}_{29}$ Triaromatic dinoflagellates sterane \\
& $\mathrm{C}_{27}, 4$-Methyltriaromatic steroid+C $\mathrm{C}_{29}, 4-$ Methyl-, $\quad$ 24-Ehytriaromatic \\
$4+7$ & steroid \\
6 & $\mathrm{C}_{29}, 3$-Methyl-, 24-Ethyltriaromatic steroid \\
7 & $\mathrm{C}_{29}, 4-$ Methyl-,24-Ethyltriaromatic steroid \\
8 & $\mathrm{C}_{28}, 3,24-$ Dimethyltriaromatic steroid \\
\hline
\end{tabular}

Table 2: Source and thermal maturity parameters computed from triaromatic steroids, aromatic dinosteroids and related compounds in

\begin{tabular}{|c|c|c|c|c|c|c|c|c|}
\hline \\
\hline & & $\mathrm{C}_{26} / \mathrm{C}_{28}$ & $\mathrm{C}_{27} / \mathrm{C}_{28}$ & & $\mathrm{~S} /(\mathrm{S}+\mathrm{R})$ & $\mathrm{S} /(\mathrm{S}+\mathrm{R})$ & & $20 \mathrm{~S} / 20 \mathrm{~S}+20 \mathrm{R}$ \\
\hline Field & $\operatorname{Depth}(\mathrm{m})$ & 20S TAS & 20R TAS & TDSI & $\mathrm{C}_{26} \mathrm{TAS}$ & $\mathrm{C}_{28} \mathrm{TAS}$ & MPI-1 & $\mathrm{C}_{29}$ \\
\hline MJI & $2079-2098$ & 0.19 & 1.09 & 0.65 & 0.10 & 0.60 & 0.25 & 0.15 \\
\hline MJI & 2299-2308 & 0.26 & 0.62 & 0.65 & 0.19 & 0.51 & 0.25 & 0.15 \\
\hline MJI & $2637-2655$ & 0.19 & 0.63 & 0.64 & 0.17 & 0.55 & 0.22 & 0.21 \\
\hline MJI & $2857-2875$ & 0.27 & 0.62 & 0.67 & 0.21 & 0.51 & 0.37 & 0.29 \\
\hline MJI & 2994-3012 & 0.25 & 0.50 & 0.62 & 0.22 & 0.52 & 0.54 & 0.30 \\
\hline MJI & $3085-3104$ & 0.19 & 0.37 & 0.61 & 0.24 & 0.51 & 0.36 & 0.40 \\
\hline MJI & $3232-3250$ & 0.18 & 0.34 & 0.55 & 0.24 & 0.51 & 0.45 & 0.46 \\
\hline MJI & $3323-3332$ & 0.15 & 0.34 & 0.53 & 0.22 & 0.51 & 0.46 & 0.52 \\
\hline MJI & $3405-3424$ & 0.20 & 0.37 & 0.57 & 0.25 & 0.51 & 0.62 & 0.48 \\
\hline MJO & $1616-1707$ & 0.32 & 1.01 & 0.54 & 0.20 & 0.63 & 0.23 & 0.16 \\
\hline MJO & $1771-1872$ & 0.29 & 0.14 & 0.62 & 0.21 & 0.59 & 0.31 & 0.41 \\
\hline MJO & 2091-2101 & 0.39 & 1.20 & 0.67 & 0.21 & 0.63 & 0.21 & 0.21 \\
\hline MJO & 2293-2366 & 0.54 & 0.66 & 0.67 & 0.28 & 0.50 & 0.47 & 0.13 \\
\hline MJO & $2570-2588$ & 0.31 & 0.78 & 0.76 & 0.20 & 0.51 & 0.38 & 0.19 \\
\hline MJO & $2808-2817$ & 0.38 & 0.84 & 0.78 & 0.20 & 0.49 & 0.35 & 0.38 \\
\hline OKN & $1537-1555$ & 0.21 & 1.07 & 0.72 & 0.40 & 0.16 & 0.16 & 0.18 \\
\hline $\mathrm{OKN}$ & $1729-1747$ & 0.08 & 1.14 & 0.77 & 0.21 & 0.31 & 0.14 & 0.14 \\
\hline OKN & $2625-2643$ & 0.13 & 1.43 & 0.63 & 0.21 & 0.11 & 0.12 & 0.30 \\
\hline OKN & $2780-2799$ & 0.17 & 0.93 & 0.79 & 0.17 & 0.44 & 0.16 & 0.24 \\
\hline OKN & 2863-2881 & 0.34 & 0.98 & 0.65 & 0.15 & 0.59 & 0.18 & 0.34 \\
\hline OKN & 2909-2927 & 0.31 & 0.79 & 0.67 & 0.16 & 0.54 & 0.22 & 0.28 \\
\hline
\end{tabular}

$C_{26} / C_{28} 20 S$ TAS = triaromatic steroids ratio $; C_{27} / C_{28} 20 R$ TAS = triaromatic steroids ratio $;$ TDSI $=$ Triaromatic dinosteroids $/($ triaromatic dinosteroids + 3-methyl-24-ethyl triaromatic steroids) index; $C_{26} T A S S /(S+R)=C_{26}$ triaromatic steroids maturity parameters; $C_{28} T A S$ $S /(S+R)=C_{28}$ triaromatic steroids maturity parameters, MPI-1 = methylphenanthrene index $1 ; 20 S /(20 S+20 R) C_{29}=C_{29}$ steranes maturity parameters.

Conclusion: Rock samples from the offshore Niger Delta basin, Nigeria were characterized by gas chromatography-mass spectrometry (GC-MS). The source rocks were found to be formed from mixed origin (terrestrial and marine) and deposited in freshwater-brackish/saline lacustrine environment within immature to early oil window maturity. This study showed that the abundance and distribution of triaromatic steroids and triaromatic dinosteroids can be used to assess the origin, depositional environments and thermal maturity of source rocks in the Niger Delta Basin.

Acknowledgements: The authors thank the Department of Petroleum Resources of Nigeria and Chevron Nigeria Limited for providing the rock samples. A.B. Ogbesejana appreciate Cheng Quan and Zhao Jiang for their assistance in the laboratory works. 
Funding: The authors gratefully acknowledge the State Key Laboratory of Petroleum Resources and Prospecting, College of Geosciences, China University of Petroleum, Beijing, China for granting A. B. Ogbesejana an international visiting research fellowship towards this research work

\section{REFERENCES}

Asif, M.; Fazeelat, T (2012). Petroleum geochemistry of the Potwar Basin, Pakistan: II - Oil classification based on heterocyclic and polycyclic aromatic hydrocarbons. App. Geochem. 27: 1655-1665.

Doust, H; Omatsola, E (1990). Niger Delta divergent/passive margin basins. AAPG Bull. Mem. 45:201-238

Ekweozor, CM; Daukoru, EM (1994). Northern delta depobelt portion of Akata-Agbada petroleum system, Niger Delta, Nigeria. In: AAPG Memoir, vol 60. American Association of petroleum Geologists, Tulsa, p. 599-614.

Evamy, BD; Haremboure, J; Kamerling, P; Knaap, WA; Molloy, FA; Rowlands, PH (1978). Hydrocarbon habitat of Tertiary Niger Delta. AAPG Bull. 62:277-298

Li, M; Wang, TG; Lillis; P.G; Wang, C; Shi, S (2012b). The significance of 24-norcholestanes, triaromatic steroids and dinosteroids in oils and Cambrian-Ordovician source rocks from the cratonic region of the Tarim Basin, NW China. App. Geochem. 27:1643-1654.

Mi, J; Zhang, S; Chen, J; Tang, L; He, Z (2007). The distribution of the oil derived from Cambrian source rocks in Lunna area, The Tarim Basin, China. Chin. Sci.Bull. 52(Suppl. I):133-140.

Moldowan, JM; Talyzina, NM (1998). Biogeochemical evidence for dinoflagellate ancestors in the Early Cambrian. Sci. 281:1681170 .
Moldowan, JM; Lee, CY; Watt, DS; Jeganathan, A; Slougui, N; Gallegos, EJ (1991). Analysis and occurrence of $\mathrm{C}_{26}$ steranes in petroleum and source rocks. Geochim. et Cosmochim Acta 55:1065-1081.

Peters, KE; Walters, CC; Moldowan, JM (2005). The Biomarker Guide, second ed. Cambridge University Press.

Radke, M (1988). Application of aromatic compounds as maturity indicators in source rocks and crude oils. Mar. Pet. Geol. 5:224-236.

Seifert, WK; Moldowan, JM (1981). Palaeoreconstruction by Biological markers. Geochimica et Cosmochimica Acta 45:783-794

Short, KC; Stauble, AJ (1967). Outline of geology of Niger Delta . AAPG 51:761-779.

Wang, G; Wang, TG; Simoneit, BRT; Chen, Z; Zhang, L; Xu, J (2008a). The distribution of molecular fossils derived from dinoflagellates in Paleogene lacustrine sediments (Bohai Bay Basin, China). Org. Geochem. 39:1512-1521.

Whiteman, A (1982). Nigeria: Its Petroleum Geology, Resources and Potentials, vol. 1 and 2. Pub. Graham and Trontman Ltd., p. 394.

Withers, N (1987). Dinoflagellates sterols. In: Taylor, F.J.R. (Ed.), The Biology of Dinoflagellates. Blackwell Scientific, Oxford, p. 316-359.

Xiangchun, C; Zuozhen, H; Xiaofei, S; Chengpeng, Y (2011). Geochemical characteristics of aromatic hydrocarbons in crude oils from the Linnan Subsag, Shandong Province, China. Chin. J. Geochem. 30:132-137

Zhang, S; Moldowan, JM; Li, M; Bian, L; Zhang, B; Wang, F; He, Z; Wang, D (2002). The abnormal distribution of molecular fossils in the pre-Cambrian and Cambrian: its biological significance. Sci. China D (Earth Sci.) 45, 193199. 